\title{
The Mediating Effect of Job Satisfaction on the Relationship between Workplace Friendships and Turnover Intention in Iran Hotel Industry
}

\author{
Reza Asgharian ${ }^{1}$ \\ Roya Anvari*2 \\ Ungku Norulkamar Ungku Bt. Ahmad ${ }^{3}$ \\ Ali Minaee Tehrani ${ }^{4}$ \\ ${ }^{1}$ Ph.D student, Faculty of Management, Universiti Teknologi Malaysia (UTM) \\ 2 Senior Lecturer, Faculty of Management, Universiti Teknologi Malaysia (UTM) \\ ${ }^{3}$ Head Department of Business Administration \& Senior Lecturer, Faculty of Management, Universiti Teknologi Malaysia (UTM) \\ ${ }^{4}$ Department of Business Management, Firoozkooh Branch, Islamic Azad University, Firoozkooh, Iran \\ *E-mail of the corresponding author: ry_anvari@yahoo.com
}

Doi:10.5901/mjss.2015.v6n6s2p304

\section{Abstract}

Job satisfaction can sparked from workplace friendship. Friendship is eminent is our everyday lives. With the increasing loss of relationships and bonding in the community and as we spent more of our times building and focusing on our careers, friendships in the workplace has becoming unavoidable. On the other hand, workplace friendship is perceived negatively by managers and administrators as it can lead to many negative consequences. This study is conducted in October 2014 in the cities of Tehran and Mashhad in Iran to identify the effects of job satisfaction as a mediating factor between friendships in the workplace with turnover intention among hotel workers. In all, 175 frontline hotel employees had answered sets of questionnaires as part of the study. In this quantitative study, the data obtained from the questionnaires were analysed using the Statistical Package for Social Science (SPSS) version 21. Statistical tests used for analysis were descriptive statistics, the Pearson coefficient test, simple regression test, multiple regression test and path analyses. The results of this study indicated that job satisfaction plays a significant role in mediating workplace friendships with turnover intentions. It is hoped that the findings of this study can help hotel managers to reduce the high turnover rates in the hostel industry as well as to the control conflicts that arises from work place friendships.

Keywords: Workplace Friendship, Job Satisfaction, Turnover Intention, Frontline Employees, Hotel Industry, Iran

\section{Introduction}

Friendship is part of human nature, hence workplace friendship is imminent as we spend more time in the workplace and less time bonding in the our neighbourhood community (Shellenbarger, 2000); workplace friendship has become a norm which either increase the sustainability of the workplace or ruin it, this is because workplace friendships can bring job satisfactions (Morrison, 2004). This happens when a personal experiences difficulties, friends in the workplace can provide support and help. Hence, when there is a positive working environment, employee cohesiveness happens. Individual will become more motivated to work, have no intention to the job. Therefore, Morrison theorised that workplace friendships reduce turnover intentions among employees. Meanwhile, the mediating factor in the relationship between workplace friendship and turnover intentions is job satisfaction. This means that the low turnover rate is in an organisation caused by having job satisfaction that is sparked by friendship in the workplace.

Issues on employee turnover have become a growing concern to researchers in the field of management such as Clifton et al (1980); Lee \& Chon (2000), Mobley (1982), Muchinsky \& Tuttle (1979) and Tett \& Meyer (1993). This is because high turnover rates can cost significant losses to the hotel industry (Hom \& Griffeth, 1995; Lee \& Chon, 2000; Mobley, 1982). As claimed by Batra and Tan (2003), employee turnover increase monetary costs; where more money are needed to recruit and re-train new employees. Next, it can jeopardise the service quality and efficacy as the amount of experienced employees is decreased. Finally, turnover in the hotel industry, can demoralise other employees, the loss of high performance employees might be damaging because other employees may lost reliable leaders in the workplace. Therefore, as mentioned in Tsaur \& Lin, (2004) supervisors and managers should ensure the retention of high performing 
employees in their organisation. In addition, for frontline employees, they play a critical role in delivery of high quality service and need to be efficient (Hartline \& Ferrell, 1996). This is they deal directly with the customers and can promote the business when they exhibit positivity and satisfaction in their work.

One way to decrease the turnover rate is the prevalence job satisfaction through the cultivation of workplace friendship. As mentioned earlier, job satisfaction is sparked by having a positive working environment in the workplace such as having a positive workplace friendship, thus, workplace friendship can be useful for the hotel industry as it can increase their employees' retention rate and consequently, increase the quality and efficacy of the services in the hotel industry. However, for many hotel managers, friendship in the workplace can create conflicts and negative consequences to the organisations. Based on this, this research attempts to investigate the relationship between friendships in the workplace and turnover intentions among frontline employees of five-star hotels in Iran. This research can contribute in improving the hospitality industry in Iran as it can add to the body of knowledge on turnover intentions. In addition, this research helps to explain the turnover intentions rates among the frontline employees in the Iranian hotel industry. Furthermore, this research will foster better understanding of workplace friendships among the hotel manager and recommend better ways to encourage positive relationships among the employees. This study is also hoped to increase the understanding about the importance of workplace friendships and in providing conducive working environment for the employees in the Iranian hospitality industry.

\subsection{Significance of study}

Firstly, this study is significant as it will try to fill in the gap in the limited resources to investigate the effects of workplace friendships to turnover intention. This will help both researchers and managers to create more understanding on the phenomena of workplace friendships and its influences to the staffs and their working environment. In addition, this research provides empirical evidences on the influence of workplace friendships in creating job satisfactions that can reduce the turnover intentions among frontline employees of hotel industry. Secondly, this research play a significant role in improving job satisfaction and the quality of service of the Iranian tourism and hospitality industry as Iran is still in its infancy stage and employee turnover is a critical problem in the hospitality industry in Iran (Anvari et al., 2014). Thirdly, this study is significant because of its aim of to investigate possible positive outcomes of workplace friendships and to change the negative disposition that organisations and managers have on workplace friendships.

\subsection{Research Objectives}

Based on the research and problems backgrounds as well as the significance of the study highlighted in the preceding sections, two research objectives are outlined, they are:

1. To identify and explain the mediating effect of job satisfaction in relationship between workplace friendship and turnover intention among frontline employees in the Iranian hotel industry.

2. To probe the current level of turnover intentions, as an indicator of job satisfaction in the Iranian hospitality industry and how it affects the quality of service.

\subsection{Research Questions}

To achieve the research objectives, two research questions have been formulated, they are as follow:

$\mathrm{R}$ Q 1: What is the mediating effect of job satisfaction in the relationship between workplace friendship and turnover intention among frontline employees in the Iranian five star hotels?

RQ 2: What is the level of employees' turnover intention and job satisfaction among frontline employees in the Iranian hotel industry?

\subsection{Research Hypothesis}

In relation to the statistical tests for this research, main null hypotheses have been generated, they are as follow:

H01: There is no significant effect of job satisfaction in the relationship between workplace friendships and the turnover intentions among frontline hotel employees in the Iranian five star hotels. industry.

H02: There is no significant level of employees' turnover intentions among front employees in the Iranian hotel 


\section{Literature Review}

\subsection{Workplace Friendships}

\subsubsection{Definition of friendships}

Friendship, is a common word in our everyday lives. However, defining it can be difficult. Bell (1981) and Fischer (1982) claimed that the meaning for the word friendship is subjective in different cultures. For many of us, friendship is a tangible concept that is experienced throughout our lifetime. Perhaps friendship can be described as relationships between individuals where they share values, mutual respects, empathy and good-time orientations through interactions among themselves, when individuals are in a friendship, they feel obligated to help each other in times of need, to listen to and understand each other's problems, as well as to protect one another (Synder \& Smith, 1986; Sias et al., 2004).

\subsubsection{The relationship between workplace friendship and job satisfaction}

Workplace friendship is the relationship between employees of an organisation that work in the same workplace. Similar to other types from friendships, workplace friendship involve sharing mutual trust, values and interests (Bermanet al., 2002; Nielsen et al., 2000). From here, job satisfaction, or as defined by Locke (1976) as the feeling of pleasure resulted from the perception of one's job is fulfilling. This is because friendship encourages empathy and employees can share problems and motivate each other. Although these positive outcomes may not solely caused by friendship, Berman et al., (2002) claimed that workplace friendship can encourage positivity in the workplace. In addition, friendship in the workplace can help develop the sense of belonging among the employees (Mitchell, Holtom \& Lee, 2001). This feeling provides comfort that creates a sense of attachment and this can lead to a higher level of employee retention.

In addition, one way workplace can cultivate job satisfaction in the workplace is it cultivates mutual commitments and trusts. This is beneficial not only for the individuals but also the hotel where they work (Berman et al., 2002). This is because workplace friendships can enhance organisational performances, as mentioned earlier, work place friendship encourages the sharing of responsibilities, furthermore, friendship ease communications among the employees, consequently, this will decrease miscommunications and increase efficacies of hotel services as well as one's job satisfaction (Markiewicz et al., 2000; Nielsen et al., 2000; Amjadet al., 2015). All of these studies have proven that workplace friendships have positive impact of increasing job satisfaction among employees.

\subsubsection{The case for workplace friendships}

Despite the fact that friendship in the workplace in inevitable, many organisations still have negative perception about it as it can lead to a seemingly serious problem. However, as discussed earlier, workplace friendship can also have positive influence in increasing the quality of work among hotel employees. As mentioned by Hamilton (2007) and Milam (2012), there is a need to advocate the positive outcomes of workplace friendships especially among hotel managers as it can relinquish negative the stigmas. Thus, based on the studies mentioned, this study will investigate the positive outcomes of workplace friendships to create a case for hotel managers to encourage workplace friendships in their hotels.

\subsection{Turnover Intention and turnover rate}

Price (2001) defined turnover as the "individual movement across the membership boundary of an organisation" (p. 600). As mentioned earlier, turnover intentions can affect an organisation's efficacy as well as their management cost. This is because while turnover can be beneficial in an organisation, as mentioned in Dalton, Todor \& Krackhardt (1982), there are many negative consequences when a large number of an organisation's employee voluntarily departed unexpectedly. Therefore, many researches, include Lambert et al., (2001), Price (2001), Hom \& Griffeth (1991) and Perez (2008) have focused on turnover intentions and turnover rates. It is believed that turnover intentions and turnover rate can predict the performance of an organisation (Hancock et al., 2013; Cohen, Blake, \& Goodman, 2015). This implies that turnover intention has multi-dimensional effects to an organisation; hence, it should not be taken lightly; having a high turnover attention among the employees have negative perception about the management, as turnover intentions indicate that the employees feel uneasy and stressed in their working environment; a high turnover rate creates great challenges to an organisation, especially the hostel industry. Turnover rate can determine a hotel's survivals in the industry (Karatepe and Olugbade, 2009; Kim et al., 2009; Christian et al., 2011). Researches from Hom and Griffeth (1991), Hinkin and Tracey 
(2000) and Pizam and Thornburg (2000) showed that high turnover rates can cause negative impacts such as the loss of revenues and the increase of operational costs, loss of productivity and low morale among the remaining employees. This is greatly apparent in the hotel industry where hotel works require back breaking intensive long hours works, low wage and have limited or no career development prospects, as reported in Clifton et al., (1980), Iverson \& Deery (1997), and Lee \& Chon, (2000). In relation to Iran, Mahmoodi (2007) has reported that there is a 35-64\% turnover rate among hotel employees while Anvari el al. (2014), claimed that Iranian hotels have higher operational costs but lower service quality caused by the high annual turnover rate. On the other hand, Karatepe \& Ehsani (2012) argued that there is a need for further investigations on the issue regarding turnover rates among hotel employees in Iran.

\subsection{Workplace Friendships, Job Satisfaction and Turnover Intention}

Turnover rate can be predetermined by various factors; Boxall, Macky \& Rasmussen (2003), Deery \& Shaw (1999), Gustafon (2002), Kang, Gatling, \& Kim (2015) claimed that job satisfaction, compensation, work environment, organisational cultures and communication are factors that determine turnover rates. All these influence the employees' job satisfaction for instance, positive work environments foster a feel of satisfaction and sense of belonging among the employees (Mitchell, Holtom and Lee, 2001). In addition, a positive organisational culture can ensure high retention rate and low turnover rate, while turnover rate can be determined by the level of communications (Mobley, 1982; Cottini, Kato \& Westergaard, 2011; Mowday, Porter, \& Steers, 2013); good and positive communication can decrease turnover rates as good communication among employees creates a positive working environment. In addition, workplace friendship can be a catalyst for job satisfaction and better communication among the employees (Berman et al., 2002). In addition, Morrison (2004) also discussed how better cohesiveness and the study also discussed that greater employee cohesiveness and the prevalence of workplace friendships resulted in the reduction in turnover intentions. Meanwhile, Winstead et al., (1995) and Self and Dewald (2011), mentioned that the strong friendships at the workplace can increase the employees' retention in their workplace, having friends and social attachments is one the most commonly cited reasons for remaining to work in an organisation aside from financial needs. This is also argued in Morrison (2004), where workplace friendship was claimed to have negative relationship with turnover rate. However, there is still a limited number of researches that focus on identifying and explaining the relationship of workplace friendship and turnover rate, especially in the hotel industry, particularly in Iran.

\subsubsection{Published scales in measuring workplace friendship}

\subsubsection{Workplace Friendship Scale (WFS)}

The workplace friendship scale (WFS) is a scale developed by Nielsen (2000) that measured the two aspects of workplace friendships- friendship prevalence and friendship opportunities, six items in the scale measured friendship opportunities, and the remaining six items measured the prevalence of friendship. This scale is controversial as there are a number of critics and opposing studies, such as Morrison (2005) and Dickie (2009). Despite this controversy, Milan (2012) argued that the WFS scale is considered the most psychometrically sound instrument for measuring workplace friendship and is the most commonly used.

\subsubsection{Published scale to measure anticipated turnover}

\subsubsection{Anticipated turnover scale (ATS)}

The Anticipated Turnover Scale (Hinshaw and Atwood, 1980) was developed to identify issues that are related with turnover among employees. The variables for this scale are the issues that affect both turnover intentions and turnover rates. Such issues include staffs characteristics and organisational structure. This scale is able to profile the characteristics of those who left and compared them to those who stayed as well as estimate the degree of such issues can predict actual turnover rates.

\subsubsection{Job Satisfaction Survey}

The Job Satisfaction Survey (JSS) as developed by Spector (1985), is a 36 item, nine factor scale that is used to measure the employees' attitudes about their job. Each factor is assessed with four items. The scale is measured using 5 
point Likert scale where 1 (strongly disagree) and 5 (strongly agree). The nine factors of job satisfaction include wage, promotion prospect, supervision, Fringe Benefits, contingent rewards, operating procedures, co-workers, nature of work, and communication. The Job Satisfaction Survey yielded a coefficient alpha of .91 for the total scale (Spector, 1985), which indicates it is a highly efficient test.

\subsection{Theoretical framework for research}

Based on the literature reviewed for this research, a theoretical framework has been developed to provide a theoretical background into the focus of this research. The framework is as follow:

This figure presents the theoretical framework of this current study. From the

\section{Research Methodology}

To investigate the relationship between workplace friendships and turnover rate, the quantitative research design with a descriptive research paradigm was adopted, as mentioned in Hair et al., (2006). Furthermore, a quantitative co-relational study was also adopted to measure the relationships. To test the hypothesis, a deductive reasoning process were conducted similar to those mentioned in Bonoma (1985), Lincoln and Guba (1985), therefore, the reasoning process moved from discussing general ideas (high turnover intentions among employees) into refining the data and theories into explaining the phenomena and relating it the independent variable, which is workplace friendship.

\subsection{Variables}

The independent variable of this study is the workplace friendship while the dependent variable of this study is the employees' turnover rate. Another variable in this research is the mediating variable which is job satisfaction. A mediating variable is the variable that 'controls' the relationship between the independent and dependent variables. By identifying these variables, it is will be easier for the researcher to study the relationship between the variables, as the dependent variable is subjective to the independent variable.

\subsection{Population and sample of the study}

The context for the study is the two Iranian cities of Tehran and Mashhad. The samples for this study are the frontline employees of five star hotels in the two cities. These frontline employees include both male and female full-time employees working as front desk agents and reservations agents. The perquisite is that they should have a minimum of one-year tenure in one of the five star hotels. In determining the total sample size for the population, the stratified sampling method was used and the number of samples was determined using Krejcie and Morgan (1987) calculation. Finally, a total of 175 frontline employees were selected from 10 five star hotels in Tehran and Mashhad.

\subsection{Data Collection Methods}

\subsubsection{Research Instrument}

The instrument used for this research is a set of questionnaire. The questionnaire is a self-administered questionnaire (SAQ) with 65 items in three sections. The questionnaire questions were designed based on the Workplace Friendship Scale (Nielsen et al., 2000) with Cronbach's alphas of .84 and .95the anticipated turnover scale (ATS), with the alpha coefficient of 0.84 and the Job Satisfaction Survey (JSS), these three scales are published tests that had been described in the chapter 2 of this paper. The distribution of the type variables in the questions are shown in the table, as follow:

Table 1: The distribution of items in the questionnaire based on the variables

\begin{tabular}{|l|c|c|}
\hline Variable & Item No. & Total Items \\
\hline Demographic & I to $\mathrm{V}$ & 12 \\
\hline Workplace Friendships & 1 to 12 & 12 \\
\hline Turnover Intention & 13 to 24 & 36 \\
\hline Job Satisfaction & 25 to 60 & \\
\hline
\end{tabular}




\subsubsection{Questionnaire reliability}

To ensure the validity of the questionnaire, a pilot test was conducted before the distribution of the final questionnaires. A total of 30 questionnaires were sent randomly via snail mail to frontline employees of five star hotels in Iran. The questionnaire was translated to the Persian language to remove the language barrier that can occur. The responses from the completed questionnaires were tested using the Cronbach alpha. The test result indicated that the instrument had acceptable internal reliability within the dimensions being assessed and could be used for further data collection. The alpha reliability results of the pilot test showed that the "coefficient alpha" of each scale was higher than 0.70 as shown in Table 2.

Table 2: Cronbach Alpha Reliability of Main constructs

\begin{tabular}{|c|l|c|c|}
\hline No. & Construct & Cronbach's Alpha & Number of Items \\
\hline 1 & Workplace Friendship & .786 & 12 \\
\hline 2 & Turnover Intention & .791 & 12 \\
\hline 3 & Job satisfaction & .868 & 36 \\
\hline
\end{tabular}

In the final stage, a total of 175 questionnaires were distributed among frontline employees of ten 5-star hotels in two Iranian cities, Tehran and Mashhad. There were 166 questionnaires that were returned to the researcher (94\%). From the 166 sets, 18 sets were rejected for the lack of answers. In all, only 148 sets of responses 989\%) were used for statistical analysis.

\section{Data Analysis and Results}

\subsection{Descriptive statistics}

Table 3 shows the results of Descriptive statistics for the variables. The table shows the minimum value, maximum value, mean vale and std. deviation for each of the variables tested

Table 3: Descriptive Statistics for Variables of Study ( $N=148$ )

\begin{tabular}{|l|c|c|c|c|}
\hline & Minimum & Maximum & Mean & Std. Deviation \\
\hline Workplace friendship & 1.00 & 5.00 & 2.8063 & .81000 \\
\hline Turnover Intention & 2.25 & 4.17 & 3.3361 & .49252 \\
\hline Job satisfaction & 1.14 & 4.97 & 2.6017 & .79299 \\
\hline
\end{tabular}

\subsection{Research Objectives and Hypotheses Testing}

$\mathrm{H}$ 1: There is a significant effect of job satisfaction on the relationship between workplace friendship and turnover intentions.

In order to obtain the result for this, a mediation analysis was conducted. The results of mediation analysis for the model WPF-JS-TI are shown in Table 4.

Table 4: Test of Mediation for WPF-JS-TI Model

\begin{tabular}{|l|c|c|c|c|c|c|c|c|c|}
\hline \multicolumn{1}{|c|}{ Model } & Description & $R$ & $R^{2}$ & Adj. $R^{2}$ & $F$ & Sig & Beta & $t$ & Sig. \\
\hline Step 1 Dependent Variable: Turnover Intention \\
\hline
\end{tabular}




\begin{tabular}{|l|c|c|c|c|c|c|c|c|c|}
\hline & .463 & .215 & .209 & 39.919 & .000 & & & \\
\hline Intercept & & & & & & 2.587 & 20.890 & .000 \\
\hline Job Satisfaction & & & & & & .288 & 6.318 & .000 \\
\hline Step 4 Dependent Variable: Turnover Intention \\
\hline \multicolumn{2}{|l|}{} & .489 & .239 & .229 & 22.792 & .000 & & & \\
\hline Intercept & & & & & & 2.477 & 18.668 & .000 \\
\hline Workplace friendship & & & & & & .153 & 2.160 & .032 \\
\hline Job Satisfaction & & & & & & .165 & 2.284 & .024 \\
\hline
\end{tabular}

The relationship between the independent variable (workplace friendship) with the dependent variable (Turnover intention) was determined in the first step. From the regression analysis, the value of $R^{2}$ was .212, which showed a $21.2 \%$ impact on turnover intention. The model fitness was authenticated as F-statistics was $39.237(p<0.05)$ and the beta value for the workplace friendship was 0.280 . The value of $t$-statistics was $6.264(p<0.05)$. These results prove the significance of the first path of the analysis.

The model fitness was authenticated here as F-statistics is $232.022(p<0.05)$ with the beta value of .767 that proves that was considered significant as $t$-statistics is $15.232(p<0.05)$. These results prove that independent variable (workplace friendship) has a significant impact on mediating variable (job satisfaction).

Next, the relationship of mediating variable (job satisfaction) and the dependent variable (turnover intention) were evaluated in step 3. The value of $R^{2}$ was.215, which showed $21.5 \%$ variations in the turnover intentions because of job satisfaction. The model fitness was authenticated by the results of step 3. The value of $F$-statistics was $39.919(p<0.05)$ with the beta value of job satisfaction was .288 with a t-statistics of $6.318(p<0.05)$. These results prove that mediating variable has a significant impact on dependent variable.

The impact of mediating variable (job satisfaction) was controlled in step 4, the value of $R^{2}$ is .239 , which showed $23.9 \%$ variation in turnover intention because of workplace friendship and job satisfaction. The model fitness was authenticated as the value of $F$-statistics was $22.792(p<0.05)$. The beta value of workplace friendship was 153 with a tstatistics of $2.160(p<0.05)$. Similarly, the beta value of mediator (job satisfaction) was .165 with a t-statistics of 2.284 ( $p$ $<0.05)$.

The results here indicated that although the beta value of workplace friendship has decreased, it is still significant. This indicates that job satisfaction partially mediates the relationship between workplace friendship and turnover intention. Therefore, the first null hypothesis is rejected and the alternative hypothesis is accepted.

Ha1: Job satisfaction has a significant effect of the relationship between workplace friendship and turnover intention. (Partially Supported) industry

H2: There is a significant level of employees' turnover intentions among front employees in the Iranian hotel

To answer the second research question and prove the test the second hypothesis, descriptive tests to obtain mean values and t-test from the data from the questionnaire were conducted. The mean values for each item that measure turnover intentions are shown in Table 5.

Table 5: Turnover Intention

\begin{tabular}{|c|c|c|c|c|c|}
\hline & Range & Minimum & Maximum & Mean & Std. Deviation \\
\hline$I 1$ & 4 & 1 & 5 & 3.36 & 1.202 \\
\hline$I 2$ & 3 & 2 & 5 & 3.64 & .976 \\
\hline$I 3$ & 4 & 1 & 5 & 3.60 & 1.093 \\
\hline$I 4$ & 4 & 1 & 5 & 3.57 & 1.095 \\
\hline$I 5$ & 4 & 1 & 5 & 3.45 & 1.208 \\
\hline I6 & 4 & 1 & 5 & 3.69 & .954 \\
\hline I7 & 4 & 1 & 5 & 3.72 & 1.143 \\
\hline I8 & 3 & 2 & 5 & 3.32 & .970 \\
\hline 19 & 4 & 1 & 5 & 3.27 & .877 \\
\hline$I 10$ & 4 & 1 & 5 & 2.82 & 1.117 \\
\hline$I 11$ & 3 & 1 & 4 & 2.99 & 1.007 \\
\hline$I 12$ & 4 & 1 & 5 & 2.59 & 1.010 \\
\hline $\mathrm{N}$ & 148 & & & 40.02 & \\
\hline
\end{tabular}


The respondents were asked to answer 12 questions regarding their turnover intentions. The questions were rated on a five point Likert scale ranging from strongly disagree (1) and strongly agree, (5). There is a minimum score of 12 and the maximum score is 60 . The scores ranging from $48-60$ are indicative of a high rate of turnover intention among frontline employees. The result indicates that there is a low rate of turnover intentions among the frontline employees of 5-star hotels of Tehran and Mashhad as indicated by the mean value (40.02).To further test the intentions of frontline employees regarding their intention to leave their jobs, a t-test was conducted with regard to their genders and marital status. The result is shown in Table 6.

Table 6: Gender and Turnover Intention

\begin{tabular}{|l|c|c|c|c|c|c|c|}
\hline \multirow{2}{*}{ Gender } & \multirow{2}{*}{ Mean } & \multirow{2}{*}{ St. dev. } & \multicolumn{3}{|c|}{ Levene's Test for Equality of Variances } & \multicolumn{3}{|c|}{ t-test for Equality of Means } \\
\cline { 1 - 5 } & & & $\mathrm{F}$ & Sig. & $\mathrm{t}$ & $\mathrm{df}$ & Sig. (2-tailed) \\
\hline Male & 3.3204 & .47391 & 1.290 & .258 & -.739 & 146 & .461 \\
\hline Female & 3.3932 & .55931 & &
\end{tabular}

The t-test result indicates that there are no significant differences between both genders. Therefore, the Levene's test for equality of variances is insignificant, which indicates that no differences exist between male and female respondents. The t-test was also conducted for marital status of the respondents. The result is shown in Table 7.

Table 7: Marital Status and Turnover Intention

\begin{tabular}{|l|c|c|c|c|c|c|c|}
\hline \multirow{2}{*}{ Status } & \multirow{2}{*}{ Mean } & \multirow{2}{*}{ St. dev. } & \multicolumn{3}{|c|}{ Levene's Test for Equality of Variances } & \multicolumn{3}{|c|}{ t-test for Equality of Means } \\
\cline { 1 - 5 } & & & $\mathrm{F}$ & Sig. & $\mathrm{t}$ & $\mathrm{df}$ & Sig. (2-tailed) \\
\hline Single & 3.3362 & .50182 & .475 & .492 & .001 & 146 & .999 \\
\hline Married & 3.3361 & .48275 & .47 & & \\
\hline
\end{tabular}

The t-test result for marital status and turnover intention indicate that there is no significant difference between the two groups regarding turnover intentions. The results of t-test further support that there is a low level of turnover intention among frontline employees of 5-star hotels in Iran. Therefore the second null hypothesis is accepted.

H02: There is no significant level of turnover rates among frontline hotel employees in Iran.

\section{Discussion}

\subsection{Analysis of Result}

The study had been conducted to investigate the mediating effect of job satisfaction in the relationship between workplace friendships and turnover intentions among frontline hotel employees in five star hotels in Mashhad and Tehran, Iran. This study was implemented by using a set of questionnaire and it can be concluded that job satisfaction has a partially significant role in mediating the relationship between workplace friendships and turnover intentions. This is in line with studies by Berman et al., (2002), Hamilton (2007) and Milam (2012) that advocated workplace friendships. This is because having a sense of belonging to the organisation creates job satisfaction among the employees, as mentioned Cottini, Kato \& Westergaard (2011), Mowday, Porter, \& Steers (2013). In addition, this research result also validates the argument by Morrison (2004) on the need for organisations and managers to eliminate the negative perceptions on workplace friendships and try to encourage it within the organisation. The data analysis also showed the mediating effect of job satisfaction in the change of the independent variable (workplace friendship) and dependent variable (workplace turnover). This shows that three elements are inexplicably linked to each other. This calls for the need for organisations and managers to not only eliminate negative stigmas on workplace friendships, but also call for them to create positive environment where friendships can strive.

The data analysis also indicates that even though the Iranian hospitality industry is still in its infancy and the quality of work may not be satisfactory, there is a significantly low level of turnover intentions among the employees. This is opposite of the perception that the turnover intentions among hotel employees are very high. 


\subsection{Recommendations}

Based on the data from the study, there is a positive outcome from workplace friendships, which is it helps reduce the turnover rates. Cutting down the turnover rates will help in cutting down costs for recruitment and retraining of new staffs as well as increasing time based expertise among the staffs. Therefore, this paper suggests two ways to promote workplace friendship, first, managers and organisations can organise activities that promote staffs to socialise with each other, not only within the same department and with other staffs of the same ranks, but also among staffs from all departments, regardless of their ranks and positions. This cross hierarchy socialising can promote bonding and friendships among the staffs all across the organisations. In addition, the managers can try to eliminate the negative stigma of workplace friendships by creating a guideline for staff friendships. This guideline can outline the ethics and code and conduct that can retain professionalism among the staffs, for example, staffs are not allowed to post negative, suggestive or degrading comments among themselves or the staffs need to conduct in professional manners in front of the customers and within their working hours.

For future studies, researches can investigate the turnover intentions among the different genders. This is because that men and women would have different career goals that are being influenced by many external and internal factors. Being a primarily patriarchal society, it will be interesting to investigate whether women in Iran are pressured to leave the job after they get married or have children.

\section{Conclusion}

In all, it is apparent that job satisfaction plays a significant role in mediating the relationship between workplace friendships and turnover intention. It can be concluded that workplace friendships can lead to job satisfaction that help reduce turnover intentions and rates among hotel staffs in general. It can be concluded that job satisfaction can mediate the relationship between workplace friendships and turnover intention; hence, turnover intention can be reduced by improving job satisfaction through encouraging workplace friendships. Therefore, managers should encourage friendships in the workplace, rather than hindering it as it can be beneficial for them. It is hoped that this study will give an apparent impact not only for the employees involved, but also all hotel staffs in general.

\section{References}

Amjad, Z., Sabri, P. S. U., llyas, M., \& Hameed, A. (2015). Informal Relationships at Workplace and Employee Performance: A Study of Employees Private Higher Education Sector. Pakistan Journal of Commerce and Social Sciences, 9(1), 303-321.

Anvari, R., Irum, S., Ashfaq, M., Atiyaye, D.M. (2014). The impact of leader's cultural intelligence on organizational commitment. Asian Social Science, 10(17), 45-51.

Anvari, R., Irum, S., Shah, I.M., Mahmoodzadeh, N., Ashfaq, M. (2014). Determinants of information technology leadership program. Review of European Studies, 6(2), 45-49.

Bandura, A. (1982). The psychology of chance encounters and life paths. American psychologist, 37(7), 747.

Batra, G., \& Tan, H. (2003). SME Technical Efficiency and Its Correlates: Cross national Evidence and Policy Implications. World Bank, Washington, DC.

Bell, R. R. (1981). Friendships of women and of men. Psychology of Women Quarterly, 5(3), 402-417.

Berman, E. M., West, J. P., \& Richter Jr, M. N. (2002). Workplace relations: Friendship patterns and consequences (according to managers). Public Administration Review, 62(2), 217-230.

Bonoma, T. V. (1985). Case research in marketing: opportunities, problems, and a process. Journal of marketing research, 199-208.

Boxall, P., Macky, K., \& Rasmussen, E. (2003). Labour turnover and retention in New Zealand: The causes and consequences of leaving and staying with employers. Asia Pacific Journal of Human Resources, 41(2), 196-214.

Christian, M. S., Garza, A. S., \& Slaughter, J. E. (2011). Work engagement: A quantitative review and test of its relations with task and contextual performance. Personnel Psychology, 64(1), 89-136.

Clifton, D. K., \& SAWYER, C. H. (1980). Positive and Negative Feedback Effects of Ovarian Steroids on Luteinizing Hormone Release in Ovariectomized Rats following Chronic Depletion of Hypothalamic Norepinephrine*. Endocrinology, 106(4), 1099-1102.

Cohen, G., Blake, R. S., \& Goodman, D. (2015). Does Turnover Intention Matter? Evaluating the Usefulness of Turnover Intention Rate as a Predictor of Actual Turnover Rate. Review of Public Personnel Administration, 0734371X15581850.

Cottini, E., Kato, T., \& Westergaard-Nielsen, N. (2011). Adverse workplace conditions, high-involvement work practices and labor turnover: Evidence from Danish linked employer-employee data. Labour Economics, 18(6), 872-880.

Dalton, D. R., Todor, W. D., \& Krackhardt, D. M. (1982). Turnover overstated: The functional taxonomy. Academy of management Review, 7(1), 117-123.

Deery, M. A., \& Shaw, R. N. (1999). An investigation of the relationship between employee turnover and organizational culture. Journal of Hospitality \& Tourism Research, 23(4), 387-400. 
Fischer, C. S. (1982). What do we mean by 'friend'? An inductive study. Social networks, 3(4), 287-306.

Gustafson, C. M. (2002). Employee turnover: a study of private clubs in the USA. International Journal of Contemporary Hospitality Management, 14(3), 106-113.

Hair, J. F., Black, W. C., Babin, B. J., Anderson, R. E., \& Tatham, R. L. (2006). Multivariate data analysis (Vol. 6). Upper Saddle River, NJ: Pearson Prentice Hall.

Hamilton, E. A. (2007). Firm friends: Examining functions and outcomes of workplace friendship among law firm associates (Vol. 68, No. 03).

Hancock, J. I., Allen, D. G., Bosco, F. A., McDaniel, K. R., \& Pierce, C. A. (2013). Meta-analytic review of employee turnover as a predictor of firm performance. Journal of Management, 39(3), 573-603.

Hartline, M.D., \& Ferrell, O.C. (1996). The Management of Customer-Contact Service Employees: An Empirical Investigation. Journal of Marketing, 60(October), 52-70.

Hinkin, T. R., \& Tracey, J. B. (2000). The cost of turnover: Putting a price on the learning curve. The Cornell Hotel and Restaurant Administration Quarterly, 41(3), 14-4.

Hinshaw, A. S., \& Atwood, J. (1980). Anticipated turnover scale: a pilot stage instrument. Communicating Nursing Research, 13(1), 56.

Hom, P. W., \& Griffeth, R. W. (1995). Employee turnover. South-Western Pub.

Iverson, R. D., \& Deery, M. (1997). Turnover culture in the hospitality industry. Human Resource Management Journal, 7(4), 71-82.

Kang, H. J., Gatling, A., \& Kim, J. (2015). The Impact of Supervisory Support on Organizational Commitment, Career Satisfaction, and Turnover Intention for Hospitality Frontline Employees. Journal of Human Resources in Hospitality \& Tourism, 14(1), 68-89.

Karatepe, O. M., \& Ehsani, E. (2012). Work-related depression in frontline service jobs in the hospitality industry: Evidence from Iran. Journal of Human Resources in Hospitality \& Tourism, 11(1), 16-35.

Karatepe, O. M., \& Olugbade, O. A. (2009). The effects of job and personal resources on hotel employees' work engagement. International Journal of Hospitality Management, 28(4), 504-512.

Kim, H. J., Tavitiyaman, P., \& Kim, W. G. (2009). The effect of management commitment to service on employee service behaviors: The mediating role of job satisfaction. Journal of Hospitality \& Tourism Research, 33(3), 369-390.

Krejcie, R. V., \& Morgan, D. W. (1970). Determining sample size for research activities. Educ Psychol Meas.

Lambert, E. G., Hogan, N. L., \& Barton, S. M. (2001). The impact of job satisfaction on turnover intent: a test of a structural measurement model using a national sample of workers. The Social Science Journal, 38(2), 233-250.

Lee, C., \& Chon, K. S. (2000). An investigation of multicultural training practices in the restaurant industry: the training cycle approach. International Journal of Contemporary Hospitality Management, 12(2), 126-134.

Lincoln, Y. S., \& Guba, E. G. (1985). Postpositivism and the naturalist paradigm. Naturalistic inquiry, 14-46.

Locke, E. A. (1976). The nature and causes of job satisfaction. Handbook of industrial and organizational psychology, 1, $1297-1343$.

Mahmoodi, S. (2007). برنامه ريزى استر اتزيك [The Strategic Planning]. مديريت , 2(3), 56-68.

Markiewicz, D., Devine, I., \& Kausilas, D. (2000). Friendships of women and men at work: Job satisfaction and resource implications. Journal of Managerial Psychology, 15(2), 161-184.

Milam, J. G. (2012). Why workplace friendships matter: An assessment of workplace friendships, employee engagement, job embeddedness, and job burnout. ALLIANT INTERNATIONAL UNIVERSITY.

Mitchell, T. R., Holtom, B. C., \& Lee, T. W. (2001). How to keep your best employees: Developing an effective retention policy. The Academy of Management Executive, 15(4), 96-108.

Mobley, W. H. (1982). Some unanswered questions in turnover and withdrawal research. Academy of Management Review, 7(1), 111116.

Morrison, R. (2004). Informal Relationships in the Workplace: Associations WItl1J0b Satisfaction, Qrganisational. New Zealand journal of psychology, 33(3).

Mowday, R. T., Porter, L. W., \& Steers, R. M. (2013). Employee-organization linkages: The psychology of commitment, absenteeism, and turnover. Academic Press.

Muchinsky, P. M., \& Tuttle, M. L. (1979). Employee turnover: An empirical and methodological assessment. Journal of Vocational Behavior, 14(1), 43-77.

Nielsen, I. K., Jex, S. M., \& Adams, G. A. (2000). Development and validation of scores on a two-dimensional workplace friendship scale. Educational and Psychological Measurement, 60(4), 628-643.

Perez, M. (2008). Turnover intent. Basılmamış Yğksek Lisans Tezi.

Pizam, A., \& Thornburg, S. W. (2000). Absenteeism and voluntary turnover in Central Florida hotels: a pilot study. International Journal of Hospitality Management, 19(2), 211-217.

Price, J. L. (2001). Reflections on the determinants of voluntary turnover. International Journal of Manpower, 22(7), 600-624.

Riordan, C. M., \& Griffeth, R. W. (1995). The opportunity for friendship in the workplace: An underexplored construct. Journal of business and psychology, 10(2), 141-154.

Self, J. T., \& Dewald, B. (2011). Why do employees stay? A qualitative exploration of employee tenure. International Journal of Hospitality \& Tourism Administration, 12(1), 60-72.

Shellenbarger, S. (2000). More relaxed boomers, fewer workplace frills and other job trends. Wall Street Journal, 27.

Sias, P. M., Heath, R. G., Perry, T., Silva, D., \& Fix, B. (2004). Narratives of workplace friendship deterioration. Journal of Social and Personal Relationships, 21(3), 321-340.

Snyder, M., \& Smith, D. (1986). Personality and friendship: The friendship worlds of self-monitoring. In Friendship and social interaction 
(pp. 63-80). Springer New York.

Snyder, M., \& Smith, D. (1986). Personality and friendship: The friendship worlds of self-monitoring. In Friendship and social interaction (pp. 63-80). Springer New York.

Spector, P. E. (1985). Measurement of human service staff satisfaction: Development of the job satisfaction survey. American journal of community psychology, 13(6), 693-713.

Tett, R. P., \& Meyer, J. P. (1993). Job satisfaction, organizational commitment, turnover intention, and turnover: path analyses based on meta-analytic findings. Personnel psychology, 46(2), 259-293.

Tsaur, S-H., \& Lin, Y-C. (2004). Promoting Service Quality in Tourist Hotels: The Role of HRM Practices and Service Behavior. Tourism Management, 25(4), 471-481.

Tsaur, S-H., \& Lin, Y-C. (2004). Promoting Service Quality in Tourist Hotels: The Role of HRM Practices and Service Behavior. Tourism Management, 25(4), 471-481.

Winstead, B. A., Derlega, V. J., Montgomery, M. J., \& Pilkington, C. (1995). The quality of friendships at work and job satisfaction. Journal of social and personal relationships, 12(2), 199-215. 